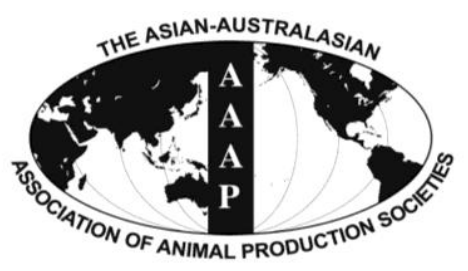

Asian Australas. J. Anim. Sci.

Vol. 26, No. 9 : 1295-1303 September 2013

http://dx.doi.org/10.5713/ajas.2013.13094

www.ajas.info

pISSN 1011-2367 elSSN 1976-5517

\title{
Rumen Fermentation and Performance of Lactating Dairy Cows Affected by Physical Forms and Urea Treatment of Rice Straw
}

\author{
P. Gunun, M. Wanapat*, and N. Anantasook \\ Tropical Feed Resources Research and Development Center (TROFREC), Department of Animal Science, \\ Faculty of Agriculture, Khon Kaen University, Khon Kaen, 40002, Thailand
}

\begin{abstract}
The aim of this study was to determine the effect of different physical forms and urea treatment of rice straw on feed intake, rumen fermentation, and milk production. Four, multiparous Holstein crossbred dairy cows in mid-lactation with initial body weight (BW) of $409 \pm 20 \mathrm{~kg}$ were randomly assigned according to a $4 \times 4$ Latin square design to receive four dietary treatments. The dietary treatments were as follows: untreated, long form rice straw (LRS), urea-treated (5\%), long form rice straw (5\% ULRS), ureatreated $(2.5 \%)$, long form rice straw $(2.5 \%$ ULRS) and urea-treated $(2.5 \%)$, chopped $(4 \mathrm{~cm})$ rice straw $(2.5 \%$ UCRS). Cows were fed with concentrate diets at a ratio of concentrate to milk yield of 1:2 and rice straw was fed ad libitum. The findings revealed significant improvements in total DM intake and digestibility by using long and short forms of urea-treated rice straw $(\mathrm{p}<0.05)$. Ruminal $\mathrm{pH}$ was not altered among all treatments ( $p>0.05)$, whereas ruminal $\mathrm{NH}_{3}-\mathrm{N}, \mathrm{BUN}$ and MUN were found to be increased $(\mathrm{p}<0.01)$ by urea-treated rice straw as compared with untreated rice straw. Volatile fatty acids (VFAs) concentrations especially those of acetic acid were decreased $(\mathrm{p}<0.05)$ and those of propionic acid were increased $(\mathrm{p}<0.05)$, thus acetic acid:propionic acid was subsequently lowered $(\mathrm{p}<0.05)$ in cows fed with long or short forms of urea-treated rice straw. The $2.5 \%$ ULRS and $2.5 \%$ UCRS had greater microbial protein synthesis and was greatest when cows were fed with 5\% ULRS. The urea-treated rice straw fed groups had increased milk yield $(\mathrm{p}<0.05)$, while lower feed cost and greater economic return was in the $2.5 \%$ ULRS and $2.5 \%$ UCRS ( $<<0.01$ ). From these results, it could be concluded that 2.5\% ULRS could replace 5\% ULRS used as a roughage source to maintain feed intake, rumen fermentation, efficiency of microbial protein synthesis, milk production and economical return in mid-lactating dairy cows. (Key Words: Rice Straw, Urea Treatment, Physical Forms, Rumen Fermentation, Microbial Protein Synthesis, Dairy Cows)
\end{abstract}

\section{INTRODUCTION}

Local feed resources, particularly agricultural cropresidues are commonly used as roughage for the feeding of dairy cows in the tropics (Wanapat et al., 2012). Rice straw is abundantly available all year in large quantities in the region (Hue et al., 2008) and when urea treated (5\%) rice straw can be used as the only source of roughage in the dry season (Wanapat et al., 2000). Urea treatment is an applicable technique for improving the quality of rice straw (Sanh et al., 2002), in terms of increasing protein content, nutrient digestibility, $\mathrm{NH}_{3}-\mathrm{N}$ concentration, VFA production (particularly propionic acid) and milk production (Hart and Wanapat, 1992; Djibrillou et al., 1998; García-Martínez et al., 2009; Wanapat et al., 2009b). Treatment of rice straw with $5 \%$ urea has been used in dairy farms but the cost is

\footnotetext{
* Corresponding Author: Metha Wanapat. Tel: +66-43-202368, Fax: +66-43-202368, E-mail: metha@kku.ac.th Submitted Feb. 9, 2013; Accepted Apr. 23, 2013; Revised May 13, 2013
}

relatively high due to the increasing price of urea (Wanapat et al., 2009b). Reducing level of urea for treating rice straw could be an effective way to reduce production cost (Khejornsart and Wanapat, 2010).

The balance of normal rumen fermentation is not only influenced by the supply of nutrients available for fermentation but may be influenced by the physical form of roughage (Mertens, 1997). An adequate amount of physical fiber is critical in maintaining proper rumen function, decreasing the risk of metabolic disorders and avoiding suppression of fiber digestion (Bhandari et al., 2008). Normally, ruminants require a long form of roughage fiber (NRC, 2001), which is useful for the maintenance of normal rumen function and has been associated with adequate salivation, optimal ruminal $\mathrm{pH}$ for cellulolytic microorganisms and energy supply (Yang et al., 2001). Although impaired rumen fermentation and function can result from ruminants fed rations lacking in roughage, excessive amounts of long, coarse roughage may also limit 
roughage intake and digestibility of nutrients (Allen, 1997), VFA production, microbial CP supply and milk production. However, there is limited published research regarding how the chop length of rice straw, with and without urea treatment, will impact feed intake, digestion, rumen fermentation and microbial CP synthesis of the diet, or performance characteristics of lactating dairy cattle. Moreover, information on other feedstuffs (i.e. barley straw, alfalfa forage, corn straw etc.) may not be easily applicable to rice straw, because of differences in chemical composition and physical form of the fiber (Mertens, 1997; Zhao et al., 2009). Therefore, the objective of this experiment was to investigate the effect of physical forms and urea treatment of rice straw on feed intake, nutrient digestibility, rumen fermentation, microbial CP synthesis and milk yield in lactating dairy cows.

\section{MATERIALS AND METHODS}

\section{Animals, treatments and experimental design}

Four, multiparous mid-lactation (92 DIM: $\pm 7 \mathrm{SD}$ ) Holstein-Friesian crossbred cows $(75 \%$ HF with $25 \%$ Thai native breed) were used in the experiment. Milk yield (preexperiment) was $10 \pm 1 \mathrm{~kg} / \mathrm{d}$ and the $\mathrm{BW}$ was $409 \pm 20 \mathrm{~kg}$. Cows were randomly assigned according to a $4 \times 4$ Latin square design. The dietary treatments were: untreated, long form rice straw (LRS); urea-treated (5\%), long form rice straw (5\% ULRS); urea-treated (2.5\%), long form rice straw $(2.5 \%$ ULRS) and urea-treated $(2.5 \%)$, chopped $(4 \mathrm{~cm})$ rice straw $(2.5 \%$ UCRS). Cows were housed in individual pens and individually fed with concentrate diets at a ratio of concentrate to milk yield of 1:2, twice daily at 06:00 am and 16:00 pm after milking. All cows were fed ad libitum rice straw as a roughage source while allowing for $10 \%$ refusals. Chemical compositions of concentrate, rice straw and ureatreated rice straw are presented in Table 1. Clean fresh water and mineral blocks were available ad libitum. The experiment was conducted for four periods, each period lasting for $21 \mathrm{~d}$, the first $14 \mathrm{~d}$ for feed intake measurements and the remaining $7 \mathrm{~d}$ for sample collection of feeds, feces, urine and milk. The BW was measured at the first and last days of sampling. Rice straw was chopped to a theoretical cut length of $4 \mathrm{~cm}$ prior to the $2.5 \%$ UCRS treatment. Ureatreated rice straw was prepared by using 5 or $2.5 \mathrm{~kg}$ of urea plus $100 \mathrm{~kg}$ water, sprayed onto $100 \mathrm{~kg}$ of straw, and then covered up for 10 days before directly feeding to the animals (Wanapat et al., 2009b).

\section{Data collection and sampling procedures}

Feed intakes and refusals were measured and recorded. Feeds were sampled daily during the collection period and were composited by period prior to analyses $(n=20)$. Feed and fecal samples were collected during the last 7 days of each period. Fresh fecal samples (about $500 \mathrm{~g}$ ) were collected twice daily by rectal grab sampling (morning and afternoon) after milking for five consecutive days and composited for storage in the freezer. Composited samples were later dried at $60^{\circ} \mathrm{C}$ and ground $(1 \mathrm{~mm}$ screen using Cyclotech Mill, Tecator) and analyzed using the standard methods of AOAC (1995) for dry matter (DM), crude

Table 1. Ingredients and chemical compositions of concentrate, rice straw and urea-treated rice straw (UTRS) used in the experiment

\begin{tabular}{|c|c|c|c|c|}
\hline Item & Concentrate & Rice straw & $5 \%$ UTRS & $2.5 \%$ UTRS \\
\hline \multicolumn{5}{|l|}{ Ingredient (\%) } \\
\hline Cassava chip & 41.0 & - & - & - \\
\hline Coconut meal & 20.3 & - & - & - \\
\hline Dried brewerys' grain & 20.2 & - & - & - \\
\hline Rice bran & 11.3 & - & - & - \\
\hline Urea & 2.7 & - & - & - \\
\hline Molasses & 2.0 & - & - & - \\
\hline Tallow & 1.0 & - & - & - \\
\hline Salt & 0.5 & - & - & - \\
\hline Sulfur & 0.5 & - & - & - \\
\hline Mineral premix & 0.5 & - & - & - \\
\hline \multicolumn{5}{|l|}{ Chemical composition } \\
\hline Dry matter (\%) & 91.0 & 91.3 & 50.7 & 50.3 \\
\hline Organic matter & 94.2 & 87.6 & 88.0 & 88.2 \\
\hline Crude protein & 18.1 & 2.4 & 7.3 & 5.0 \\
\hline Neutral detergent fiber & 47.2 & 80.7 & 78.2 & 78.5 \\
\hline Acid detergent fiber & 17.2 & 58.7 & 56.3 & 57.0 \\
\hline Ash & 5.8 & 10.9 & 12.4 & 12.0 \\
\hline Total digestible nutrients ${ }^{1}$ & 75.2 & 51.0 & 51.2 & 51.2 \\
\hline
\end{tabular}

${ }^{1}$ Calculated values. 
protein (CP), ash, neutral detergent fiber (NDF), acid detergent fiber (ADF) (Van Soest et al., 1991) and acidinsoluble ash (AIA). AIA was used to estimate digestibility of nutrients (Van Keulen and Young, 1977).

Urine samples (about $100 \mathrm{~mL}$ ) were collected by spot sampling (morning and afternoon) after milking. Urination was induced by manual stimulation of the vulva. Samples were analyzed for allantoin (IAEA, 1997) and creatinine (Hawk et al., 1976). The amount of microbial purines absorbed was calculated from purine derivative (PD) excretion based on the relationship derived by Chen and Gomes (1995). Microbial crude protein (MCP) $(\mathrm{g} / \mathrm{d})=$ $3.99 \times 0.856 \times$ mmoles of purine derivatives excreted (Galo et al., 2003). The efficiency of microbial $\mathrm{N}$ synthesis (EMNS) [ $\mathrm{g}$ of $\mathrm{N} / \mathrm{kg}$ of organic matter $(\mathrm{OM})$ digested in the rumen $(\mathrm{OMDR})]$, assuming that rumen digestion $=65 \%$ of $\mathrm{OM}$ digestible in total tract (ARC, 1990).

Daily milk yield of each cow was recorded and individual milk samples were collected twice daily, morning and afternoon milkings, preserved with 2-bromo-2 nitropropane-1, 3-dial, and stored at $4^{\circ} \mathrm{C}$ until analysis. Milk composition including fat, protein, lactose, total solids, and solid-not-fat were determined by infrared methods using Milko-Scan 33 (Foss Electric, Hillerod, Denmark). Milk urea nitrogen (MUN) was determined using Sigma kits \#640 (Sigma Diagnostics, St. Louis, MO). Economic return (feed cost, milk sale and margin over feed) were calculated.

At the end of each period, rumen fluid samples were collected by using a stomach tube and vacuum pump at 0 and $4 \mathrm{~h}$ post-feeding. Approximate $200 \mathrm{~mL}$ of rumen fluid was collected at each time from the middle part of the rumen using a $60 \mathrm{~mL}$ hand syringe. Temperature and $\mathrm{pH}$ of rumen fluid were measured using a portable $\mathrm{pH}$ and temperature meter (Hanna Instruments HI 8424 microcomputer, Singapore). Rumen fluid samples were then filtered through 4 layers of cheesecloth. Samples were used for $\mathrm{NH}_{3}-\mathrm{N}$ analysis to which $5 \mathrm{~mL}$ of $1 M \mathrm{H}_{2} \mathrm{SO}_{4}$ was added to $50 \mathrm{~mL}$ of rumen fluid. The mixture was centrifuged at $16,000 \times \mathrm{g}$ for $15 \mathrm{~min}$, and the supernatant was stored at $-20^{\circ} \mathrm{C}$ before $\mathrm{NH}_{3}-\mathrm{N}$ analysis using Kjeltech Auto 1030 Analyzer (Bremmer and Keeney, 1965) and VFA analysis using HPLC (Samuel et al., 1997).

A blood sample (about $10 \mathrm{~mL}$ ) was collected from the jugular vein at the same time as rumen fluid sampling into tubes containing $12 \mathrm{mg}$ of EDTA and plasma was separated by centrifugation at $500 \times \mathrm{g}$ for $10 \mathrm{~min}$ at $4^{\circ} \mathrm{C}$ and stored at $-20^{\circ} \mathrm{C}$ until analysis of blood urea nitrogen (BUN) according to Crocker (1967).

\section{Statistical analysis}

Statistical analyses were performed using the general linear procedure in PROC GLM of SAS (1996). Data were analyzed using the model $Y_{i j k}=\mu+M_{i}+A_{j}+P_{k}+\varepsilon_{i j k}$, where $Y_{i j k}$ = observation from treatment $i$, animal $j$ and period $k$; $\mu$, the overall mean, $M_{i}=$ the mean effect of treatments ( $i=1$ to 4 ); $A_{j}=$ the mean effect of animals $\left(j=1\right.$ to 4 ); $P_{k}=$ the mean effect of periods ( $k=1$ to 4 ) and $\varepsilon_{i j k}$ the residual error. Multiple comparisons among treatment means were performed by Duncan's New Multiple Range Test (Steel and Torrie, 1980). Differences among means with $p<0.05$ were accepted as representing statistically significant differences.

\section{RESULTS AND DISCUSSION}

\section{Feed intake, nutrient intake and apparent digestibility coefficients}

The effect of physical forms of urea-treated rice straw on feed intake, nutrient intake and digestibility is presented in Table 2. Rice straw intake in terms of $\mathrm{kg} / \mathrm{d}$ was greater for $2.5 \%$ ULRS and $2.5 \%$ UCRS, and the greatest was in the $5 \%$ ULRS (from 4.9 to $5.8 \mathrm{~kg} / \mathrm{d})(\mathrm{p}<0.05)$. Therefore, total DM intake was subsequently improved (from 10.2 to $11.9 \mathrm{~kg} / \mathrm{d}(\mathrm{p}<0.01)$ for the urea-treated rice straw fed groups. Several studies (Wanapat et al., 1985; Oji et al., 2007; Mapato et al., 2010) on the use of urea as a source of ammonia for the straw treatment found an increase in the feed intake of ruminants. Similarly, Gunun and Wanapat (2012) reported that roughage intake was greater for ureatreated $(3 \%)$ long form or chopped rice straw $(5.7 \mathrm{~kg} / \mathrm{d})$ than for untreated long form or chopped rice straw (4.8 $\mathrm{kg} / \mathrm{d}$ ).

Feed intake will be restricted when ruminants receive rice straw (Distel et al., 1994) because the rate of digestion is slow and distension of the rumen wall may limit intake (Grovum, 1988). In addition to providing nitrogen, urea treatment supplied more moisture content than in the untreated rice straw and lead to the softening of roughage fiber with the resulting reduction of the mastication load as well as fermentation enhancement in the rumen of cows. In addition, nutrient intake and digestibility coefficients of $\mathrm{OM}$, $\mathrm{CP}, \mathrm{NDF}$ and ADF were increased $(\mathrm{p}<0.05)$ by urea-treated rice straw when compared with untreated rice straw. Prasad et al. (1998) reported that the nutrient digestibility of OM, $\mathrm{CP}$ and of the fiber fractions were higher for urea treated straw rations than for untreated straw fed to crossbred cows. Wanapat et al. (2009b) reported that urea-treated (5.5\%) rice straw could improve nutrient digestibility in dairy cows. Moreover, Dutta et al. (2004) and Gunun and Wanapat (2012) reported that urea-treated rice straw could improve digestibility of NDF and ADF in goats or dairy steers. Increased nutrient digestibility was also reported (Nurfeta et al., 2009) as urea treatment of rice straw affected the cleavage of linkages between lignin, hemicelluloses and cellulose that caused the structural fibers to swell. Hence, it 
Table 2. Effects of physical forms and urea treatment of rice straw on feed intake and nutrient digestibility in lactating dairy cows

\begin{tabular}{|c|c|c|c|c|c|c|}
\hline \multirow{2}{*}{ Item } & \multicolumn{4}{|c|}{ Dietary treatment $^{1}$} & \multirow{2}{*}{ SEM } & \multirow{2}{*}{ p-value } \\
\hline & LRS & $5 \%$ ULRS & $2.5 \%$ ULRS & $2.5 \%$ UCRS & & \\
\hline \multicolumn{7}{|l|}{ Roughage DM intake } \\
\hline $\mathrm{kg} / \mathrm{d}$ & $4.9^{\mathrm{a}}$ & $5.8^{\mathrm{b}}$ & $5.5^{\mathrm{bc}}$ & $5.3^{\mathrm{c}}$ & 0.11 & 0.01 \\
\hline$\% \mathrm{BW}$ & $1.3^{\mathrm{a}}$ & $1.5^{\mathrm{b}}$ & $1.4^{\mathrm{ab}}$ & $1.4^{\mathrm{ab}}$ & 0.03 & 0.03 \\
\hline $\mathrm{g} / \mathrm{kg} \mathrm{BW}^{0.75}$ & $55.8^{\mathrm{a}}$ & $65.4^{\mathrm{b}}$ & $61.9^{\mathrm{b}}$ & $61.3^{\mathrm{b}}$ & 1.38 & 0.03 \\
\hline \multicolumn{7}{|l|}{ Total DM intake } \\
\hline $\mathrm{kg} / \mathrm{d}$ & $10.2^{\mathrm{a}}$ & $11.9^{\mathrm{b}}$ & $11.4^{\mathrm{b}}$ & $11.3^{\mathrm{b}}$ & 0.20 & 0.007 \\
\hline$\% \mathrm{BW}$ & $2.6^{\mathrm{a}}$ & $3.0^{\mathrm{b}}$ & $2.9^{\mathrm{b}}$ & $2.9^{\mathrm{b}}$ & 0.03 & 0.01 \\
\hline $\mathrm{g} / \mathrm{kg} \mathrm{BW}^{0.75}$ & $115.8^{\mathrm{a}}$ & $132.9^{\mathrm{b}}$ & $128.8^{\mathrm{b}}$ & $129.8^{\mathrm{b}}$ & 1.31 & 0.01 \\
\hline \multicolumn{7}{|l|}{ Estimated energy intake $^{2}$} \\
\hline ME (Mcal/d) & 25.1 & 28.7 & 28.3 & 27.9 & 1.04 & 0.20 \\
\hline ME (Mcal/kg DM) & 2.7 & 2.7 & 2.7 & 2.7 & 0.06 & 0.99 \\
\hline \multicolumn{7}{|l|}{ Nutrients intake $(\mathrm{kg} / \mathrm{d})$} \\
\hline Organic matter & $9.5^{\mathrm{a}}$ & $11.0^{\mathrm{b}}$ & $10.6^{\mathrm{b}}$ & $10.5^{\mathrm{b}}$ & 0.15 & 0.008 \\
\hline Crude protein & $0.9^{\mathrm{a}}$ & $1.4^{\mathrm{b}}$ & $1.1^{\mathrm{c}}$ & $1.2^{\mathrm{c}}$ & 0.04 & 0.003 \\
\hline Neutral detergent fiber & $6.5^{\mathrm{a}}$ & $7.5^{\mathrm{b}}$ & $7.1^{\mathrm{b}}$ & $7.1^{\mathrm{b}}$ & 0.13 & 0.02 \\
\hline Acid detergent fiber & $3.8^{\mathrm{a}}$ & $4.3^{\mathrm{b}}$ & $4.3^{\mathrm{b}}$ & $4.1^{\mathrm{b}}$ & 0.06 & 0.04 \\
\hline \multicolumn{7}{|c|}{ Digestibility coefficients (\%) } \\
\hline Dry matter & 63.4 & 65.7 & 66.1 & 66.2 & 1.64 & 0.99 \\
\hline Organic matter & $68.0^{\mathrm{a}}$ & $73.2^{\mathrm{b}}$ & $72.3^{\mathrm{b}}$ & $72.5^{\mathrm{b}}$ & 1.02 & 0.02 \\
\hline Crude protein & $59.5^{\mathrm{a}}$ & $70.3^{\mathrm{b}}$ & $63.9^{\mathrm{c}}$ & $65.1^{\mathrm{c}}$ & 1.46 & 0.01 \\
\hline Neutral detergent fiber & $52.8^{\mathrm{a}}$ & $63.1^{\mathrm{b}}$ & $60.2^{\mathrm{b}}$ & $61.0^{\mathrm{b}}$ & 1.94 & 0.02 \\
\hline Acid detergent fiber & $47.1^{\mathrm{a}}$ & $54.7^{\mathrm{b}}$ & $53.2^{\mathrm{b}}$ & $54.3^{\mathrm{b}}$ & 1.64 & 0.04 \\
\hline
\end{tabular}

resulted in increased surface area available for rumen microbes to attack structural carbohydrates, and greater degradability of fiber (Wanapat and Cherdthong, 2009).

\section{Characteristics of ruminal fermentation and blood metabolites}

The effect of the physical forms of urea-treated rice straw on rumen fermentation and BUN are presented in
Table 3. Ruminal $\mathrm{pH}$ is a very important variable to indicate function of the rumen ecology. In the present study, ruminal $\mathrm{pH}$ was not affected ( $\mathrm{p}>0.05)$ by long or short forms of urea-treated rice straw. This observation is consistent with Schroeder et al. (2003). However, Allen (1997) found that forage particle length had the most influence on the range of ruminal $\mathrm{pH}$. Zhao et al. (2009) reported that ruminal $\mathrm{pH}$ was positively correlated to particle size of roughage; as

Table 3. Effects of physical forms and urea treatment of rice straw on rumen fermentation and BUN in lactating dairy cows

\begin{tabular}{|c|c|c|c|c|c|c|}
\hline \multirow{2}{*}{ Item } & \multicolumn{4}{|c|}{ Dietary treatment $^{1}$} & \multirow{2}{*}{ SEM } & \multirow{2}{*}{ p-value } \\
\hline & LRS & $5 \%$ ULRS & $2.5 \%$ ULRS & $2.5 \%$ UCRS & & \\
\hline $\mathrm{pH}$ & 6.8 & 6.8 & 6.8 & 6.7 & 0.04 & 0.34 \\
\hline $\mathrm{NH}_{3}-\mathrm{N}(\mathrm{mg} / \mathrm{dL})$ & $9.0^{\mathrm{a}}$ & $12.8^{\mathrm{b}}$ & $12.0^{\mathrm{b}}$ & $15.0^{\mathrm{c}}$ & 0.42 & 0.01 \\
\hline BUN (mg/dL) & $8.9^{\mathrm{a}}$ & $12.5^{\mathrm{b}}$ & $11.5^{\mathrm{b}}$ & $13.9^{\mathrm{c}}$ & 0.62 & 0.02 \\
\hline Total VFA (mM) & $105.6^{\mathrm{a}}$ & $128.6^{\mathrm{b}}$ & $116.9^{\mathrm{a}}$ & $128.8^{\mathrm{b}}$ & 3.80 & 0.03 \\
\hline \multicolumn{7}{|l|}{ VFA (mol/100 mol) } \\
\hline Acetic acid (C2) & $72.6^{\mathrm{a}}$ & $64.3^{\mathrm{b}}$ & $67.0^{\mathrm{b}}$ & $68.0^{\mathrm{b}}$ & 1.28 & 0.04 \\
\hline Propionic acid (C3) & $19.7^{\mathrm{a}}$ & $27.8^{\mathrm{b}}$ & $25.0^{\mathrm{bc}}$ & $23.8^{\mathrm{c}}$ & 1.23 & 0.01 \\
\hline Butyric acid (C4) & 7.7 & 7.9 & 8.0 & 8.2 & 0.28 & 0.79 \\
\hline $\mathrm{C} 2: \mathrm{C} 3$ & $4.3^{\mathrm{a}}$ & $2.4^{\mathrm{b}}$ & $2.8^{\mathrm{b}}$ & $2.9^{\mathrm{b}}$ & 0.23 & 0.02 \\
\hline
\end{tabular}

${ }^{1}$ LRS = Untreated long form rice straw; 5\% ULRS = Urea-treated (5\%), long form rice straw; $2.5 \%$ UCRS = Urea-treated (2.5\%), long form rice straw; $2.5 \%$ UCRS $=$ Urea-treated $(2.5 \%)$, chopped $(4 \mathrm{~cm})$ rice straw.

${ }^{a, b, c}$ Means in the same row with different superscripts differ $(\mathrm{p}<0.05)$. 
particle size decreases, ruminal $\mathrm{pH}$ decreases. These results clearly showed that the short form of rice straw increases rumination activity, then increases the salivary secretion flow into the rumen and thus buffers the ruminal $\mathrm{pH}$ resulting in the maintenance of normal rumen function, microorganisms and fiber digestibility. Ruminal $\mathrm{pH}$ of all diets was in the range of 6.7 to 6.9. These values were optimal for normal rumen fermentation, microorganisms and microbial synthesis of VFA and protein (Wanapat, 1999; Anantasook et al., 2013). Van Soest (1994) suggested that the $\mathrm{pH}$ range for optimal microbial activity was 6.2 to 7.2. In this study, reduced rice straw particle size had no effect on rumen $\mathrm{pH}$. The concentrations of ruminal $\mathrm{NH}_{3}-\mathrm{N}$ and BUN were increased $(\mathrm{p}<0.05)$ with urea treatment and was highest in the $2.5 \%$ UCRS. The $\mathrm{NH}_{3}-\mathrm{N}$ concentration was increased with $2.5 \%$ UCRS which could be due to reduced particle size, and more attachment sites could lead to greater microbial colonization (Selim et al., 2004). Ruminal $\mathrm{NH}_{3}-\mathrm{N}$ concentrations averaged $12.2 \mathrm{mg} / \mathrm{dL}$ and were close to the optimal ruminal $\mathrm{NH}_{3}-\mathrm{N}$ range (12 to $17 \mathrm{mg} / \mathrm{dL}$, Wanapat and Pimpa, 1999; Mapato et al., 2010; Lunsin et al., 2012) for rumen ecology, fermentation and optimal microbial growth (Satter and Slyter, 1974; Anantasook and Wanapat, 2012). Increasing rumen $\mathrm{NH}_{3}-\mathrm{N}$ concentrations resulted in increasing concentrations of BUN when cows were fed with urea-treated rice straw. Concentrations of BUN are highly correlated to the $\mathrm{NH}_{3}$ concentrations in the rumen (Wanapat et al., 2008).

The concentration of total VFA was increased $(\mathrm{p}<0.05)$ by $5 \%$ ULRS and $2.5 \%$ UCRS. There were variations in the proportions of acetic acid and propionic acid $(\mathrm{p}<0.05)$ in which acetic acid decreased while propionic acid increased, thus $\mathrm{C} 2$ : $\mathrm{C} 3$ was subsequently lowered $(\mathrm{p}<0.05)$ in cows fed with urea-treated rice straw when compared with LRS. In addition, production of propionic acid was greater in $2.5 \%$ UCRS and were greatest in 5\% and $2.5 \%$ ULRS. These results could be due to treatment of straw increasing the population of microbes responsible for carbohydrate degradation. Increases in ruminal propionate concentration have been reported by Wanapat et al. (2009b). Butyric acid was not influenced by dietary treatments $(\mathrm{p}>0.05)$. Total VFA concentrations in all treatments ranged from 105.6 to $128.8 \mathrm{mM}$ and were similar to those reported by Wanapat et al. (2009a).

\section{Efficiency of microbial protein synthesis}

The effects of the physical forms of urea-treated rice straw on the excretion of urinary purine derivatives (PD) and microbial CP supply in dairy cows are reported in Table 4. Allantoin was the main PD detected in the urine of cows, and its excretion ranged from 132.2 to $186.9 \mathrm{mmol} / \mathrm{d}$ which was in the same range as the values previously reported for cows fed rice straw (145.2 to $258.0 \mathrm{mmol} / \mathrm{d}$; Cherdthong et al., 2011). The PD excreted in urine originates from absorbed microbial purines and purine from animal tissues (Chen et al., 1992). Moreover, urinary PD excretion is used to predict or estimate ruminal microbial protein synthesis in ruminants (Yáñez Ruiz et al., 2004). In the present study, urinary allantoin excretion and absorption were greater $(p<0.05)$ for $2.5 \%$ ULRS and $2.5 \%$ UCRS and was the greatest in the 5\% ULRS, which led to the increase in microbial CP synthesis $(\mathrm{p}<0.05)$. The EMNS based on organic matter truly digested in the rumen was enhanced in

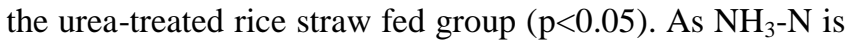
a most important and major source for microbial $\mathrm{CP}$ synthesis in the rumen (Bryant, 1974), this result could be due to urea treatment of straw increasing $\mathrm{NH}_{3}-\mathrm{N}$ concentration (12.8 to $15.0 \mathrm{mg} / \mathrm{dL}$ ) and more $\mathrm{NH}_{3}-\mathrm{N}$ for microbial utilization during ruminal fermentation. Urine creatinine was not affected by the physical forms of the rice straw or by treatment with urea $(p>0.05)$. The MCP flow from the rumen as calculated from purine derivative excretion using the equation of Chen and Gomes (1995) ranged from 451.2 to $767.1 \mathrm{~g} / \mathrm{d}$, respectively.

\section{Milk production and composition}

The influence of physical forms of urea-treated rice straw on yields and composition of milk in dairy cows are shown in Table 5. Cows which received long or short forms of urea-treated rice straw had higher $(\mathrm{p}<0.05)$ milk

Table 4. Effects of physical forms and urea treatment of rice straw on excretion of urinary purine derivatives, and microbial CP synthesis in lactating dairy cows

\begin{tabular}{|c|c|c|c|c|c|c|}
\hline \multirow{2}{*}{ Item } & \multicolumn{4}{|c|}{ Dietary treatment $^{1}$} & \multirow{2}{*}{ SEM } & \multirow{2}{*}{ p-value } \\
\hline & LRS & $5 \%$ ULRS & $2.5 \%$ ULRS & $2.5 \%$ UCRS & & \\
\hline \multicolumn{7}{|c|}{ Urinary purine derivatives $(\mathrm{mmol} / \mathrm{d})$} \\
\hline Allantoin excretion & $132.2^{\mathrm{a}}$ & $224.7^{\mathrm{b}}$ & $186.9^{c}$ & $168.1^{\mathrm{c}}$ & 9.86 & 0.02 \\
\hline Allantoin absorption & $105.3^{\mathrm{a}}$ & $241.2^{\mathrm{b}}$ & $183.0^{\mathrm{c}}$ & $157.4^{\mathrm{c}}$ & 13.57 & 0.01 \\
\hline Urine creatinine & 8.4 & 10.0 & 5.7 & 9.5 & 1.87 & 0.66 \\
\hline Microbial CP (g/d) & $451.2^{\mathrm{a}}$ & $767.1^{\mathrm{b}}$ & $638.6^{\mathrm{c}}$ & $574.0^{\mathrm{c}}$ & 22.01 & 0.03 \\
\hline EMNS (g N/kg OMDR) & $15.3^{\mathrm{a}}$ & $21.8^{\mathrm{b}}$ & $20.0^{\mathrm{bc}}$ & $18.3^{\mathrm{c}}$ & 0.84 & 0.02 \\
\hline
\end{tabular}


Table 5. Effects of physical forms and urea treatment of rice straw on milk yield, composition and economic return in lactating dairy cows

\begin{tabular}{|c|c|c|c|c|c|c|}
\hline \multirow{2}{*}{ Item } & \multicolumn{4}{|c|}{ Dietary treatment $^{1}$} & \multirow{2}{*}{ SEM } & \multirow{2}{*}{$\mathrm{p}$ value } \\
\hline & LRS & $5 \%$ ULRS & $2.5 \%$ ULRS & $2.5 \%$ UCRS & & \\
\hline \multicolumn{7}{|l|}{ Production } \\
\hline Milk yield (kg/d) & $10.6^{\mathrm{a}}$ & $12.1^{\mathrm{b}}$ & $11.9^{\mathrm{b}}$ & $12.0^{\mathrm{b}}$ & 0.36 & 0.03 \\
\hline $3.5 \%$ FCM $(\mathrm{kg} / \mathrm{d})$ & $11.1^{\mathrm{a}}$ & $12.6^{\mathrm{b}}$ & $12.2^{\mathrm{b}}$ & $12.9^{\mathrm{b}}$ & 0.24 & 0.04 \\
\hline \multicolumn{7}{|l|}{ Milk composition (\%) } \\
\hline Fat & 3.8 & 3.8 & 3.6 & 4.0 & 0.20 & 0.78 \\
\hline Protein & 3.1 & 3.2 & 3.2 & 3.1 & 0.03 & 0.94 \\
\hline Lactose & 4.7 & 4.7 & 4.7 & 4.7 & 0.05 & 0.96 \\
\hline Solids-not-fat & 8.5 & 8.6 & 8.6 & 8.6 & 0.07 & 0.99 \\
\hline Total solids & 12.1 & 12.1 & 11.9 & 12.3 & 0.16 & 0.89 \\
\hline MUN (mg/dL) & $10.1^{\mathrm{a}}$ & $14.1^{\mathrm{b}}$ & $11.4^{\mathrm{a}}$ & $15.9^{\mathrm{b}}$ & 0.56 & 0.03 \\
\hline \multicolumn{7}{|c|}{ Economic return (Thai Baht ${ }^{2} /$ cow $/ \mathrm{d}$ ) } \\
\hline \multicolumn{7}{|l|}{ Feed cost } \\
\hline Roughage cost & $9.8^{\mathrm{a}}$ & $16.5^{\mathrm{b}}$ & $13.2^{\mathrm{c}}$ & $12.8^{\mathrm{c}}$ & 0.28 & 0.001 \\
\hline Concentrate cost & $46.8^{\mathrm{a}}$ & $53.5^{\mathrm{b}}$ & $52.3^{\mathrm{b}}$ & $52.7^{\mathrm{b}}$ & 0.33 & 0.006 \\
\hline Total feed cost & $56.6^{\mathrm{a}}$ & $70.0^{\mathrm{b}}$ & $65.5^{\mathrm{c}}$ & $65.5^{\mathrm{c}}$ & 0.44 & 0.001 \\
\hline Milk sale & $191.3^{\mathrm{a}}$ & $218.7^{\mathrm{b}}$ & $213.8^{\mathrm{b}}$ & $215.6^{\mathrm{b}}$ & 2.34 & 0.004 \\
\hline Margin over feed & $134.7^{\mathrm{a}}$ & $148.7^{\mathrm{b}}$ & $148.3^{\mathrm{b}}$ & $150.1^{\mathrm{b}}$ & 1.03 & 0.006 \\
\hline
\end{tabular}

production (milk yield and 3.5\% FCM) than those fed on long form of untreated rice straw. Similarly, Vu et al. (1999) reported that urea-treated rice straw increased milk production. Wanapat et al. (2009b) reported that milk yield tended to be increased with urea-treated rice straw. However, Mapato et al. (2010) reported that urea-treated rice straw did not affect milk production of lactating dairy cows. Glucose is important for milk synthesis (Rigout et al., 2003) and in this study more energy and protein was provided by urea treatment of straw in the form of propionic acid and microbial protein in the rumen, thus there was an improved efficiency of milk synthesis and milk yield. Moreover, the total solids, fat, protein, lactose, solidsnot-fat in milk were not influenced by dietary treatments ( $>0.05)$. These results were in agreement with Dutta et al. (2004) who reported that milk composition was not affected by urea treatment of wheat straw. In contrast, Wanapat et al. (2009b) reported that $5.5 \%$ urea-treated rice straw gave greater milk protein and fat concentrations than untreated rice straw. Reduction in the particle size of roughages decrease rumination activity, fiber digestibility, ruminal $\mathrm{pH}$, decrease ruminal acetate concentration and may precipitate milk fat depression (Grant et al., 1990). Krause and Combs (2003) found that a reduction of roughage particle size reduced milk fat percentage in diets containing both corn silage and alfalfa silage. Mertens (1997) reported that a reduction in physically effective fiber causes a greater reduction in milk fat percentage in diets with a low physically effective fiber and low rumen $\mathrm{pH}$ compared with diets with a high physical effective fiber content and a high rumen $\mathrm{pH}$. In the present study, milk fat content was not affected by different physical forms of roughage. The greater fiber digestibility, ruminal $\mathrm{pH}$ (6.7) and acetate concentration may be a factor in maintaining milk fat.

Cows fed on 5\% ULRS and $2.5 \%$ UCRS had higher $(\mathrm{p}<0.05)$ MUN than $2.5 \%$ ULRS and LRS. Similarly, Wanapat et al. (2009b) found that dairy cows fed on UTRS had increased MUN levels (14.5 to $15.8 \mathrm{mg} / \mathrm{dL}$ ) and improved rumen fermentation through increased digestibility and intake of straw. MUN is the fraction of milk protein that is derived from BUN and it is proportional to the value of BUN. BUN was increased in urea-treated rice straw fed group, which led to greater MUN concentration in milk. MUN concentrations in all treatments ranged from 10.1 to $15.9 \mathrm{mg} / \mathrm{dL}$ and were close to optimal MUN range (5.6 to $17.8 \%$, Roseler et al., 1993; Wanapat et al., 2009b; Mapato et al., 2010). Roughage and total feed cost was greater $(\mathrm{p}<0.01)$ in the $2.5 \%$ ULRS and $2.5 \%$ UCRS groups and was the greatest in the 5\% ULRS. Economic analysis of milk sales clearly demonstrated that the higher margin over feed was obtained by urea-treated rice straw fed groups compared with untreated rice straw $(\mathrm{p}<0.01)$ (Table 5). Similarly, García-Martínez et al. (2009) reported that sale price of milk and profit was enhanced by 
urea treated maize straw.

\section{CONCLUSIONS AND RECOMMENDATIONS}

Based on this study, it could be concluded that treatment of long form straw with $2.5 \%$ urea resulted in improved rumen fermentation, efficiency of microbial $\mathrm{N}$ synthesis, feed intake, digestibility of nutrients, milk yield as well as an economical return when compared with untreated rice straw, while these results were similar to those in the urea-treated (5\%), long form rice straw group but the costs were greater in this group. Therefore, ureatreated $(2.5 \%)$, long form rice straw was recommended as a roughage source for lactating dairy cows which is practical for the use under farm conditions.

\section{ACKNOWLEDGEMENTS}

The authors would like to express their most sincere thanks to Tropical Feed Resources Research and Development Center (TROFREC), Khon Kaen University, Graduate School of Khon Kaen University for providing financial support for the research and use the of the research facilities.

\section{REFERENCES}

Allen, M. S. 1997. Relationship between fermentation acid production in the rumen and the requirement for physically effective fiber. J. Dairy Sci. 80:1447-1462.

Ananatasook, N., and M. Wanapat. 2012. Influence of rain tree pod meal supplementation on rice straw based diets using in vitro gas fermentation technique. Asian-Aust. J. Anim. Sci. 25:325-334.

Anantasook, N., M. Wanapat, A. Cherdthong, and P. Gunun. 2013. Effect of plants containing secondary compounds with palm oil on feed intake, digestibility, microbial protein synthesis and microbial population in dairy cows. Asian Australas. J. Anim. Sci. 26:820-826.

AOAC. 1995. Official method of analysis, 16th ed. Animal Feeds: Association of Official Analytical Chemists, Virginia, USA.

ARC. 1990. The nutrient requirements of ruminant livestock. Suppl. 1, Commonwealth Agricultural Bureaux, Slough, Farnham Royal, UK.

Bremmer, J. M., and D. R. Keeney. 1965. Steam distillation methods to determination of ammonium, nitrate and nitrite. Anal. Chim. Acta 32:485-495.

Bryant, M. P. 1974. Nutritional features and ecology of predominant anaerobic bacteria of the intestinal tract. Am. J. Clin. Nutr. 27:1313-1319.

Bhandari, S. K., S. Li, K. H. Ominski, K. M. Wittenberg, and J. C. Plaizier. 2008. Effects of the chop lengths of alfalfa silage and oat silage on feed intake, milk production, feeding behavior, and rumen fermentation of dairy cows. J. Dairy Sci. 91:19421958.

Chen, X. B., and M. J. Gomes. 1995. Estimation of microbial protein supply to sheep and cattle based on urinary excretion of purine derivative-an overview of the technique details. Occasional Publication 1992. International Feed Resources Unit, Rowett Research Institute, Aberdeen, UK.

Chen, X. B., Y. K. Chen, M. F. Franklin, E. R. Ørskov, and W. J. Shand. 1992. The effect of feed intake and body weight on purine derivative excretion and microbial protein supply in sheep. J. Anim. Sci. 70:1534-1542.

Cherdthong, A., M. Wanapat, and C. Wachirapakorn. 2011. Effects of urea-calcium mixture in concentrate containing high cassava chip on feed intake, rumen fermentation and performance of lactating dairy cows fed on rice straw. Livest. Sci. 136:76-84.

Collaway, T. R., J. E. Keen, T. S. Edrington, L. H. Baumgard, L. Spicer, E. S. Fonda, K. E. Griswold, T. R. Overton, M. E. VanAmburgh, R. C. Anderson, K. J. Genovese, T. L. Poole, R. B. Harvey, and D. J. Nisbet. 2005. Fecal prevalence and diversity of Salmonella species in lactating dairy cattle in four states. J. Dairy Sci. 88:3603-3608.

Crocker, C. L. 1967. Rapid determination of urea nitrogen in serum or plasma without deproteinization. Am. J. Med. Technol. 33:361-365.

Distel, R. A., J. J. Villalba, and H. E. Laborde. 1994. Effects of early experience on voluntary intake of low-qualily roughage by sheep. J. Anim. Sci. 72:1191-1195.

Djibrillou, O. A., V. S. Pandey, S. A. Gouro, and A. Verhulst. 1998. Effect of urea-treated or untreated straw with cotton seed on performances of lactating Maradi (Red Sokoto) goats in Niger. Livest. Prod. Sci. 55:117-125.

Dutta, N., K. Sharma, and U. Naulia. 2004. Nutritional evaluation of lentil (Lens culinaris) straw and urea treated wheat straw in goats and lactating buffaloes. Asian-Aust. J. Anim. Sci. 17:1529-1534.

Galo, E., S. M. Emanuele, C. J. Sniffen, J. H. White, and J. R. Knapp. 2003. Effects of a polymer-coated urea product on nitrogen metabolism in lactating Holstein dairy cattle. J. Dairy Sci. 86:2154-2162.

García-Martínez, A., B. Albarrán-Portillo, O. A. Castelán-Ortega, A. Espinoza-Ortega, and C. M. Arriaga-Jordán. 2009. Urea treated maize straw for small-scale dairy systems in the highlands of Central Mexico. Trop. Anim. Health Prod. 41:1487-1494.

Grant, R. J., and V. F. Colenbrander. 1990. Milk fat depression in dairy cows: Role of particle size of alfalfa hay. J. Dairy Sci. 73:1823-1833.

Grovum, W. L. 1988. Appetite, palatability and control of feed intake. In: The Ruminant Animal (Ed. D. C. Church). PrenticeHall, Englewood Cliffs, NJ, pp. 202-216.

Gunun, P., and M. Wanapat. 2012. Effect of physical form of ureatreated rice straw on nitrogen balance, rumen fermentation and nutrient digestibility in dairy steers. Khon Kaen Agric. J. 40 (Suppl.):62-68.

Hart, F. J., and M. Wanapat. 1992. Physiology of digestion of ureatreated rice straw in swamp buffaloes. Asian-Aus. J. Anim. Sci. 5:617-622.

Hawk, P. B., B. L. Oser, and W. H. Summerson. 1976. Practical Physiological Chemistry, 14th ed. McGraw Hill Publishing Company Ltd., London, UK.

Hue, K. T., D. T. T. Van, and I. Ledin. 2008. Effect of supplement 
in urea treated rice straw and molasses with different forage species on the performance of lambs. Small Rumin. Res. 78:134-143.

IAEA. 1997. Determination of purine derivative in urine. In: Estimation of the Rumen Microbial Protein Production from Purine Derivatives in Rumen. Animal Production and Health Section. Vienna, Austria. p. 49.

Kearl, L. C. 1982. Nutrient requirements of ruminants in developing countries. International Feedstuff Institute, Utah Agri. Exp. Sta, Utah State University, Logan, USA.

Khejornsart, P., and M. Wanapat. 2010. Effect of chemical treatment of rice straw on rumen fermentation characteristic, anaerobic fungal diversity in vitro. J. Anim. Vet. Adv. 9:30703076.

Krause, K. M., and D. K. Combs. 2003. Effects of forage particle size, forage source, and grain fermentability on performance and ruminal $\mathrm{pH}$ in midlactation cows. J. Dairy Sci. 86:13821397.

Lunsin, R., M. Wanapat, and P. Rowlinson. 2012. Effect of cassava hay and rice bran oil supplementation on rumen fermentation, milk yield and milk composition in lactating dairy cows. Asian-Aust. J. Anim. Sci. 25:1364-1373.

Mapato, C., M. Wanapat, and A. Cherdthong. 2010. Effect of urea treatment of straw and dietary level of vegetable oil on lactating dairy cows. Trop. Anim. Health Prod. 42:1635-1642.

Mertens, D. R. 1997. Creating a system for meeting the fiber requirements of dairy cows. J. Dairy Sci. 80:1463-1481.

NRC. 2001. Nutrient requirements of dairy cattle, 7th rev. ed. National Research Council. National Academy of Science, Washington, DC, USA.

Nurfeta, A., A. Tolera, L. O. Eik and F. Sundstøl. 2009. Feeding value of enset (Ensete ventricosum), Desmodium intortum hay and untreated or urea and calcium oxide treated wheat straw for sheep. J. Anim. Physiol. Anim. Nutr. 93:94-104.

Oji, U. I., H. E. Etim, and F. C. Okoye. 2007. Effects of urea and aqueous ammonia treatment on the composition and nutritive value of maize residues. Small Rumin. Res. 69:232-236.

Prasad, R. D. D., M. R. Reddy, and G. V. N. Reddy. 1998. Effect of feeding baled and stacked urea treated rice straw on the performance of crossbred cows. Anim. Feed Sci. Technol. 73:347-352.

Rigout, S., C. Hurtaud, S. Lemosquet, A. Bach, and H. Rulquin. 2003. Lactational effect of propionic acid and duodenal glucose in cows. J. Dairy Sci. 86:243-253.

Roseler, D. K., J. D. Ferguson, C. J. Sniffen, and J. Herrema. 1993. Dietary protein degradability effect on plasma and milk urea nitrogen and milk nonprotein nitrogen in Holstein cows. J. Dairy Sci. 76:525-534.

Samuel, M., S. Sagathewan, J. Thomus, and G. Mathen. 1997. An HPLC method for estimation of volatile fatty acids of rumen fluid. Indian J. Anim. Sci. 67:805-807.

Sanh, M. V., H. Wiktorsson, and L. V. Ly. 2002. Effect of partial replacement of green grass by urea treated rice straw in winter on milk production of crossbred lactating cows. Asian-Aust. J. Anim. Sci. 15:543-548.

SAS. 1996. SAS user's guide: Statistic, Version 5 Edition, SAS. Inst Cary, NC., USA.

Satter, L. D., and L. L. Slyter. 1974. Effect of ammonia concentration on rumen microbial protein production in vitro.
Br. J. Nutr. 32:199-208.

Schroeder, M. M., H. W. Soita, D. A. Christensen, G. R. Khorasani, and J. J. Kennelly. 2003. Effect of total mixed ration particle size on rumen $\mathrm{pH}$, chewing activity and performance in dairy cows. Asian-Aust. J. Anim. Sci. 16:1755-1762.

Selim, A. S. M., J. Pan, T. Takano, T. Suzuki, S. Koike, Y. Kobayashi, and K. Tanaka. 2004. Effect of ammonia treatment on physical strength of rice straw, distribution of straw particles and particle-associated bacteria in sheep rumen. Anim. Feed Sci. Technol. 115:117-128.

Steel, R. G. D., and J. H. Torrie. 1980. Principles and procedure of statistics: A Biometrical Approach, 2nd ed. New York: McGraw-Hill Book Company, New York, USA.

Van Keulen, J., and B. A. Young. 1977. Evaluation of acid insoluble ash as a neutral marker in ruminant digestibility studies. J. Anim. Sci. 44:282-287.

Van Soest, P. J. 1994. Nutritional ecology of the ruminant, 2nd ed. Cornell University Press, Ithaca, New York, USA.

Van Soest, P. J., J. B. Robertson, and B. A. Lewis. 1991. Method for dietary fiber, neutral detergent fiber and non-starch polysaccharide in relation to animal nutrition. J. Dairy Sci. 74:3583-3597.

Vu, D. D., L. X. Cuong, C. A. Dung, and P. H. Hai. 1999. Use of urea molasses multinutrient block and urea treated rice straw for improving dairy cattle productivity in Vietnam. Prev. Vet. Med. 38:187-193.

Wanapat, M. 1999. Feeding of ruminants in the tropicals base on local feed resources. Khon Kaen Publishing Company Ltd., Khon Kaen, Thailand.

Wanapat, M., and O. Pimpa. 1999. Effect of ruminal $\mathrm{NH}_{3}-\mathrm{N}$ levels on ruminal fermentation, purine derivatives, digestibility and rice straw intake in swamp buffaloes. Asian-Aus. J. Anim. Sci. 12:904-907.

Wanapat, M., and A. Cherdthong. 2009. Use of real-time PCR technique in studying rumen cellulolytic population as affected by level of roughage in swamp buffalo. Curr. Microbiol. 58:294-299.

Wanapat, M., F. Sundstøl, and T. H. Garmo. 1985. A comparison of alkali treatment methods to improve the nutritive value of straw. I. Digestibility and metabolizability. Anim. Feed Sci. Technol. 12:295-309.

Wanapat, M., S. Chumpawadee, and P. Paengkoum. 2000. Utilization of urea-treated rice straw and whole sugar cane crop as roughage sources for dairy cattle during the dry season. Asian-Aus. J. Anim. Sci. 13:474-477.

Wanapat, M., A. Cherdthong, P. Pakdee, and S. Wanapat. 2008. Manipulation of rumen ecology by dietary lemongrass (Cymbopogon citrates Stapf.) powder supplementation. J. Anim. Sci. 86:3497-3503.

Wanapat, M., R. Pilajun, and P. Kongmun. 2009a. Ruminal ecology of swamp buffalo as influenced by dietary sources. Anim. Feed Sci. Technol. 151:205-214.

Wanapat, M., S. Polyorach, K. Boonnop, C. Mapato, and A. Cherdthong. 2009b. Effects of treating rice straw with urea or urea and calcium hydroxide upon intake, digestibility, rumen fermentation and milk yield of dairy cows. Livest. Sci. 125:238-243

Wanapat, M., R. Pilajun, S. Kang, K. Setyaningsih, and A. R. Setyawan. 2012. Effect of ground corn cob replacement for 
cassava chip on feed intake, rumen fermentation and urinary derivatives in swamp buffaloes. Asian-Aust. J. Anim. Sci. 25:1124-1131.

Yáñez Ruiz, D. R., A. Moumen, A. I. Martín García, and E. Molina Alcaide. 2004. Ruminal fermentation and degradation patterns, protozoa population, and urinary purine derivatives excretion in goats and wethers fed diets based on two-stage olive cake: Effect of PEG supply. J. Anim. Sci. 82:2023-2032.
Yang, W. Z., K. A. Beauchemin, and L.M. Rode. 2001. Effects of grain processing, forage to concentrate ratio, and forage particle size on rumen $\mathrm{pH}$ and digestion by dairy cows. J. Dairy Sci. 84:2203-2216.

Zhao, X. G., M. Wang, Z. L. Tan, S. X. Tang, Z. H. Sun, C. S. Zhou, and X. F. Han. 2009. Effects of rice straw particle size on chewing activity, feed intake, rumen fermentation and digestion in goats. Asian-Aust. J. Anim. Sci. 22:1256-1266. 